\title{
Richard A. Lanham, The Economics of Attention: Style and Substance in the Age of Information
}

2006, 326 pp, \$29.00

\section{David Hirshleifer}

Published online: 25 February 2009

(C) The Author(s) 2009. This article is published with open access at Springerlink.com

\section{Style as an attention technology: The economics of cognitive resource allocation}

Some books pay back the price of admission in just a single chapter. The last chapter of Daniel Dennett's (1978) Brainstorms illustrated philosophical questions about the nature of consciousness with a vivid first-person story in which a man injured in a mining accident experiences brain surgery and full-body prostheses. The last chapter of Dawkins' The Selfish Gene introduced the concept of the meme, which has rallied battalions of enthusiasts and critics to the study of cultural evolution. Both books are fascinating from start to finish, but if some malicious god of endings had expunged the earlier chapters, either book would still shine.

Lanham's Economics of Attention has its own slambang chapter-which is not to deprecate the rest of the book. Every student of the economics of copyright should read 'Barbie and the Teacher of Righteousness: Two Lessons in the Economics of Attention.' What more could you want? - an entertaining story, verbal pyrotechnics, a sexy protagonist-with none of the guilt of reading a junk novel. Instead, it explores the subtleties of assigning credit for creative contributions, and the tradeoffs between rewarding creativity by granting monopoly power over the use of ideas, versus the benefits of letting others freely vary, apply and extend. Despite the stylistic differences, some parallel ideas can be found in Michele Boldrin and David Levine's (2006), Against Intellectual Monopoly.

Not that The Economics of Attention is limited to issues of copyright. It romps in a big playground, exploring the motives and evolutionary background of style, the role of style in consumer products, and how consumer attention and style interact.

D. Hirshleifer $(\bowtie)$

Paul Merage School of Business, University of California, Irvine, CA, USA

e-mail: david.h@uci.edu 
Where does evolution come in? Style, Lanham suggests, can be a way for males to signal their high abilities and resources to potential mates, an idea touched upon in Lanham's (2004), The Motives of Eloquence, and more recently covered in depth in Geoffrey Miller (2000), The Mating Mind. I will discuss a different role for evolution in a moment.

What is the point of style? According to Lanham, style is the means by which attention is attracted and allocated. Style is regulated by intellectual property law, which basically determines who has the right to use certain kinds of baits for people's attention. In the information age, Lanham argues that style, not 'stuff', becomes the greatest contributor to economic value. In consequence, the humanities are destined to become more economically important than the physical sciences and engineering-good news for underpaid English professors. And Lanham, a distinguished Professor Emeritus of English at UCLA, has put his (willingness to accept) money where his mouth is, in his role as president of a successful literary consultancy, Rhetorica, Inc. However hard it may be to know the dancer from the dance, Lanham offers many examples of the triumph of style over stuff.

A mundane economic explanation for the shift from stuff to fluff is the rise of wealth, which induces income effects. For a family living at subsistence, 'stuff' like food, clothing, clean water, and shelter, is vital. Wealth makes room for style; we expect style to be a strongly superior good. (Have economists tested this prediction?) New information technology has reduced the cost of producing and distributing both physical products such as books, and informational products such as news and music. Presumably the bigger effect is the drastic reduction in the cost of distributing information, 'fluff', over the internet.

What Lanham calls the economics of attention, most economists would call the technology of attention. So despite the rising importance of information as a product, economists like me who have been studying the allocation of attention won't get rich. The new tycoons will be what I will call attention engineers - those advertising firms, media experts, designers, artists, and professors of rhetoric who can apply the psychology of attention to provide the style that consumers demand.

Lanham gives a friendly warning to academic economists: 'In such an economy, who are the economists? No longer will they be found in economics departments but instead in the disciplines that study how attention is allocated.' Indeed, Lanham devotes a chapter to 'Economists of Attention' (italics added). But his warning is aimed at the wrong target-it is physical scientists and engineers, not economists, who are specialists in stuff. Since the 1970s, the study of information has been a fabulous success story for economic theory. On the other hand, it is only recently that a literature has started to coalesce on how limited attention affects economic decisions and markets. Some examples include Hirshleifer and Teoh (2003) and Peng and Xiong (2006).

Another big theme of Lanham's is what he calls oscillatio, the shifting of attention back and forth between sizzle and steak, style and substance, fluff and stuff, emergent pattern and detailed substrate, looking 'at' style versus looking 'through' it. New information technologies, Lanham suggests, can help ease oscillatio, which 'sharpens this tool, lubricates human invention and expression.' Style and substance are not enemies; the alternating movement of oscillatio adds meaning and creates pleasure. 
(Am I skating near double entendre? Only to illustrate what a master attention engineer Lanham is!) Lanham's oscillatio can help explain the addictive power of style and the arts, and the tendency (reflected in the assumptions of some economic models of addiction) for the investment of time and effort in critical appreciation to be rewarded with greater pleasure in the future.

Despite the title, this is not the book an economist would write. Lanham does not aim to provide a systematic analysis of the tradeoffs involved with allocating attention, equilibrium market prices for attention, and so forth. The Economics of Attention dazzles, which is only partly praise. The ideas are not all easy to carve up into working parts. Readers with a scientific bent will probably wish for more systematic taxonomy, clearer definition of terms, and more concrete delineation of the implications of the theories offered. However, Attention provides a number of perspectives on some fertile territories that economists have not mapped out and explored.

Lanham persuasively argues that the popular 'clarity-brevity-sincerity' model for human communication (do not let the wrapping obscure the content) is gravely deficient. 'Imagine what would happen if you lived your life according to such precepts... in a disinterested zeal for the naked truth. After a day or two of this you'd lose your job and your family, and the next day your mind, too.' But when is style a good that individuals should be glad to pay for, and when is it a deceitful lure used to prey upon them? Who gains, who loses, and, given conflicts of interest in communication games, what kinds of rhetoric or style will in equilibrium emerge? These are not the questions that Lanham poses. But Lanham does provide a fund of insights, vividly expressed (including engaging visuals), and ready for the attention of the analytical social scientist.

I believe that ultimately the spread of styles in society, and more generally how ideas capture public attention, will be studied as phenomena of cultural evolution. Stylistic features of cars, jokes, and political postures evolve through a process of modification and selection. If we view evolving cultural traits as replicating (whether we should is a contentious issue), then they are Dawkins' (1989) memes. Regardless, individual decisions and social interactions set the conditions for the evolution of cultural traits, and cultural innovations—good 'style' among them-which are good at grabbing favorable attention grow in popularity. What can we learn by taking such an evolutionary perspective? We don't know yet. But economists may in some ways be especially well positioned to develop theories of cultural evolution, because economists have a well-developed set of methods for modeling individual optimization (imperfectly rational or otherwise), social interactions, and the resulting equilibrium.

In any case, Lanham highlights something that economists have neglected: style as a technology for directing human attention. Although I'm sure it's true that when music gets cheaper, people will listen to more of it, it would be intellectually unambitious to limit the economics of style and culture to standard consumption theory applied to one more kind of commodity. Similarly, it is worthwhile and interesting to analyze the consequences of the notion that if advertising gives a product prestige value, people will pay more for it. But an intellectually satisfying economics of attention will not leave the most interesting part of this story (why does advertising give some products more prestige value than others?) exogenous. A deep economics of 
attention will require digging into the technology of attention allocation. To this end, The Economics of Attention provides a rich vein of examples and insights.

Open Access This article is distributed under the terms of the Creative Commons Attribution Noncommercial License which permits any noncommercial use, distribution, and reproduction in any medium, provided the original author(s) and source are credited.

\section{References}

Boldrin, M., \& Levine, D. (2006). Against intellectual monopoly. http://levine.sscnet.ucla.edu/general/ intellectual/against.htm.

Dawkins, R. (1989). The selfish gene (2nd Ed.). Oxford: Oxford University Press.

Dennett, D. C. (1978). Brainstorms: Philosophical essays on mind and psychology. USA: Bradford Books. Hirshleifer, D., \& Teoh, S. H. (2003). Limited attention, information disclosure, and financial reporting. Journal of Accounting and Economics, 36(1-3), 337-386. December.

Lanham, R. A. (2004). The motives of eloquence: Literary rhetoric in the Renaissance. Eugene, USA: Wipf and Stock Publishers.

Miller, G. (2000). The mating mind. New York: Doubleday.

Peng, L., \& Xiong, W. (2006). Investor attention, overconfidence and category learning. Journal of Financial Economics, v80(3), 563-602. 